\title{
A Lírica Colorida de Cruz e Sousa
}

\section{RESUMO}

Adailton Almeida Barros

adailton.almeida.barros@gmail.com Universidade Federal de Rondônia, Porto Velho, Brasil.
Este artigo tem como foco estudar a obra de Cruz e Sousa, poeta de singularidade ímpar na lírica brasileira. Ele foi, sem dúvida, fundante para a lírica moderna de nosso país, pois inovou seu processo criativo, preso aos moldes parnasianos, para uma poesia, ainda que acanhada, de estrutura mais livre, abusada em sugestões sensoriais, sobretudo por meio das sinestesias visuais que conferem sentidos ampliados aos seus textos. Tais características fez com que sua produção chegasse até nós como um espectro de cores que nos faz ter uma cosmovisão da sua condição existencial. O Objeto principal desse trabalho são as cores preponderantes em cada livro e suas relações com a construção semântico-temática dos livros analisados. Neste estudo, as análises serão amparadas nas noções da semântica das cores de Chevalier e Gheerbrant. Também destacamos a importância dos estudos de Bastide, Coutinho, Moisés, dentre outros em nossa fundamentação teórica e analítica.

PALAVRAS-CHAVE: Cruz e Sousa. Sinestesias visuais. Cores. 


\section{INTRODUÇÃO}

Cruz e Sousa, poeta precursor do movimento simbolista no Brasil com a publicação dos livros Broquéis e Missal (1893) e vinculado a essa estética, abusou dos recursos sinestésicos, sobretudo das sinestesias visuais no tocante ao uso abusivo de cores, especialmente numa recorrência característica deste movimento que é o uso da cor branca.

O poeta catarinense, muitas vezes, é tido como obsessivo pela cor branca, o que não procede, pois podemos verificar que a cor branca é um recurso estilístico amplamente empregado também por outros poetas simbolistas, como Alphonsus de Guimaraens, por exemplo, em poemas como "Ossea Mea", "Cisnes Brancos", "Terceira Dor", "A Catedral".

Este suposto excesso da cor branca na poética cruzesouseana chamou a atenção de alguns críticos, tanto que Roger Bastide chegou a insinuar que este abuso de que faz Cruz e Sousa da cor branca pressupõe complexo de cor. Tal concepção vem mais de um choque preconceituoso, pois é sabido que Cruz e Sousa escreveu em pleno período abolicionista e que, no início de sua carreira literária, defendeu a causa negra nos jornais e, também, na literatura, pois possui alguns poemas que versam sobre a questão do negro como podemos notar em poemas como: "Pandemonium", "Escravocratas", "Dilema", dentre outros. Percebemos ainda em muitos de seus poemas verdadeiros gritos de denúncia e repúdio às injustiças sociais e uma latente dor, um bom exemplo é o poema "Emparedado". Portanto, aos olhos de uma sociedade acostumada apenas com poetas brancos, é de se espantar um negro que outrora questionava o sistema escravocrata, tivesse em seus textos inúmeros registros da cor branca.

$\mathrm{Na}$ tradição e na cultura ocidental a cor branca representa a paz, a espiritualidade e também a luz, assim, a poesia de Cruz e Sousa por tratar de uma busca incessante pela ascensão, tanto social como espiritual para sair de sua "Vida Obscura" parte desta concepção ocidental dessa cor.

Mas, a poesia de Cruz e Sousa não fica restrita à cor branca, há diversas outras cores significativas em sua obra. Diante desta constatação, nosso objetivo é investigar os usos que ele faz das sinestesias visuais que sugerem outras cores. Para tanto, buscaremos a função primeira desta figura, ou seja, o colorido sugerido pelas imagens evocadas, os seus significados e as possibilidades semânticas existentes neste leque de cores que se encontra na poesia cruzsouseana.

Considerando que o movimento simbolista, em início oriundo da pintura impressionista, é natural que as cores se revelem como algo importante para esta estética, pois, assim como na pintura impressionista, as cores são um dos recursos necessário para se compreender o simbolismo e o sentido dos poemas, além disso, um dos preceitos simbolistas é sugerir e não descrever, sendo que o uso de cores se reveste de importantes pistas para se desvendar os poemas.

A sinestesia é uma figura de linguagem característica da estética simbolista. Em se tratando da sinestesia visual, se mostra nos poemas especialmente por meio de cores, assim, é necessário redobrar a atenção para este detalhe e ao conteúdo imagístico dos textos poéticos. 
Na poesia de Cruz e Sousa, as sinestesias visuais se revelam um expediente para tentar dar um colorido as suas imagens e sugerir o que transcende ao mero descricionismo das cenas. Deste modo, as cores funcionam como instrumento para identificar as imagens, muitas vezes, difíceis de serem visualizadas, pois se trata de uma poesia que se reporta ao mundo dos sonhos, enfim dos símbolos e requer alto poder de abstração.

Tendo por base os estudos de Bastide (1973), a proposta desta pesquisa é ampliar o que foi investigado sobre as significações das cores na poética de Cruz e Sousa. Para tanto, serão analisadas suas três obras de poemas: Broquéis, Faróis e Últimos Sonetos, diferindo do que fez Bastide que voltou sua análise para as obras Broquéis e Missal, sendo esta última uma obra em prosa poética.

As obras foram analisadas considerando a contribuição semântica das cores aos poemas, partindo dos estudos de Chevalier e Gheerbrant (1982), no tocante ao que se refere aos aspectos simbólicos das cores.

\section{CRUZ E SOUSA SIMBOLISTA}

O movimento simbolista, originário da França, foi um movimento que surgiu primeiramente entre os poetas e artista franceses e que logo tomou toda a Europa e chegou ao Brasil, devido aos livros franceses serem muito lidos, uma moda no país no século XIX. Considera-se como precursor do movimento simbolista mundial o francês Charles Baudelaire, e não somente desta estética literária, mas, sobretudo por ter inaugurado na poesia o conceito de modernidade. Segundo Massaud Moisés (1984) Baudelaire com suas Flores do mal marcou uma revolução na poesia universal, pois contrapõe a poesia "bela" muito em voga na estética anterior, à poesia que trata do feio, de temas satânicos. Sua influência se fez notar ainda no plano de expressão, graças às "Correspondências", em que faz aproximações entre as realidades físicas e sensoriais, seres, cores, perfumes e pensamentos ou emoções.

As influências baudelairianas são marcantes no nosso maior simbolista, pois no livro de poemas, Broquéis, publicado em 1893 que inaugurou oficialmente esta estética no Brasil, o primeiro poema intitulado "Antífona", apresenta a estética inovadora de Baudelaire, que a época instaurou no Brasil uma nova sensibilidade poética e moderna.

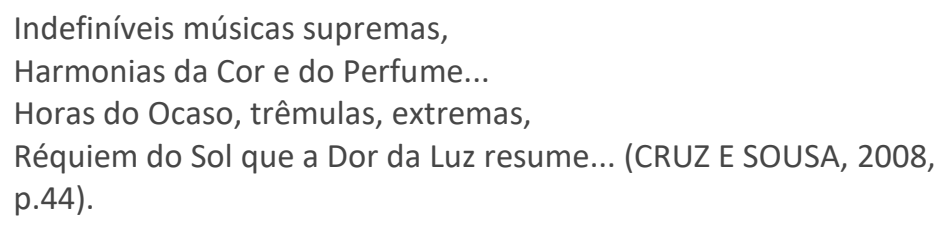

Em relação à estrofe destacada de "Antífona", Álvaro Faleiros em seu artigo "Verso e Reverso: alguma presença francesa na poesia brasileira" parafraseia Ivan Teixeira que identifica o seguinte: 
formando, por analogia, estranhas e sensoriais harmonias. Verificase, contudo, em Cruz e Sousa, uma ruptura com a sequência lógica e o abandono de uma compreensão semântica explícita, ainda mais radical do que em Baudelaire e mais próxima, por isso, do construtivismo de Mallarmé. Domina uma vaga sugestão nas relações entre os versos, reforçada pelas insistentes reticências. $O$ único verbo de toda a estrofe apenas "resume" a série de justaposições; o que faz da sintaxe do poema um mecanismo estrutural de sugestão, indício claro da radicalidade inventiva e formal presente na poética de Cruz e Sousa. (FALEIROS, 2010, p.179).

Podemos dizer que o Simbolismo fez na literatura o que o movimento Impressionista estava fazendo nas artes visuais e na música, isto é, proporcionou a solvência da figura, a perda dos contornos, a percepção individual da realidade, a interferência da luz, a fantasia, as imagens sublimes, o subjetivo, o momento, a intuição. Para Costa (2011) esses movimentos registram a impressão que a realidade provoca no espírito do artista num momento individual, as sensações que ela provoca, ou seja, demonstram a subjetividade do artista, seja ele o pintor ou poeta. O homem se volta para as questões metafísicas, espirituais, transcendentais.

Costa (2011) diz ainda que ambos os movimentos, Simbolismo e Impressionismo, são uma reação contra o materialismo e o cientificismo que imperavam no fim do século XIX. Fugindo ao mundo físico e real o artista parte em busca da essência do ser humano, daquilo que ele tem de mais recôndito. $O$ homem procura o seu verdadeiro "âmago", e não aquele eu do Romantismo, gasto e esvaziado, que se tornara superficial e excessivamente sentimentalista.

Dado à estética simbolista ter sido oriunda da pintura impressionista, é nisto que encontramos a grande importância que as cores exercem na poética de Cruz e Sousa devido à transfiguração, ao embaçamento que o poeta confere às formas, ao mundo físico. Corroborando com tal pensamento Bastide diz o seguinte:

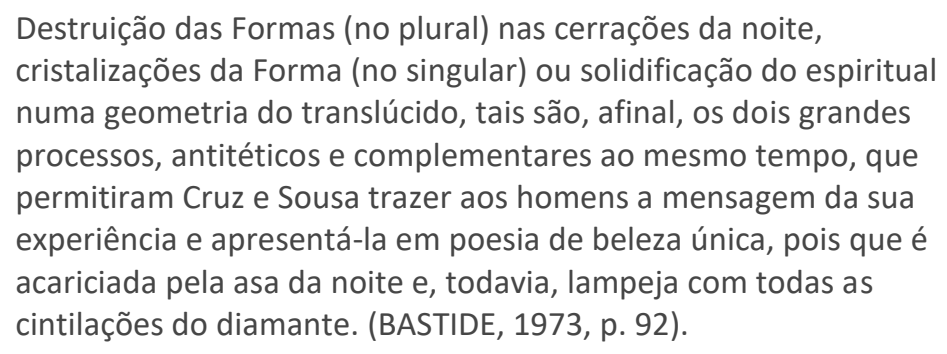

Cruz e Sousa, sobretudo em sua poesia, representou o dualismo Branco/Preto, talvez isso se deva ao drama existencial do poeta tão marcado por essa dicotomia, contudo é perceptível o contraste existente em sua poesia, em especial, se compararmos os poemas de Broquéis como os poemas "Em sonhos...", "Braços", "Sonho branco", "Cristais" com poemas de Faróis do quais podemos citar "Olhos do sonho", "Música da morte..." é interessante notar que alguns destes poemas tratam do sonho; enquanto em Broquéis temos sonhos que apontam para uma positividade, imagens claras, nítidas, envolta em luzes espirituais que remetem a perspectivas radiantes no caminhar do eu lírico, muito 
embora já em Broquéis há o prenúncio de uma turvação dos sonhos como podemos ver na última estrofe do poema Sonho branco:

No entanto, ó Sonho branco de quermesse!

Nessa alegria em que tu vais, parece

que vais infantilmente amortalhado! (CRUZ E SOUSA, 2008, p.57).

Já em Faróis, percebemos um enegrecimento dos sonhos, as perspectivas claras da luz de Broquéis são misturadas à treva de Faróis dando lugar ao acinzentado muito presente nos poemas deste livro. Os poemas de Faróis são marcados pelo viver trágico do eu lírico, as perspectivas claras, o colorido, os sons claros e harmoniosos quase que desaparecem dos poemas, revelando uma trágica orquestra, onde os sons são turbulentos e as cores agressivas, onde a música não é mais a "Música misteriosa" que ainda sob o efeito da turvação transmitia claridade, em Faróis temos a "Música da morte":

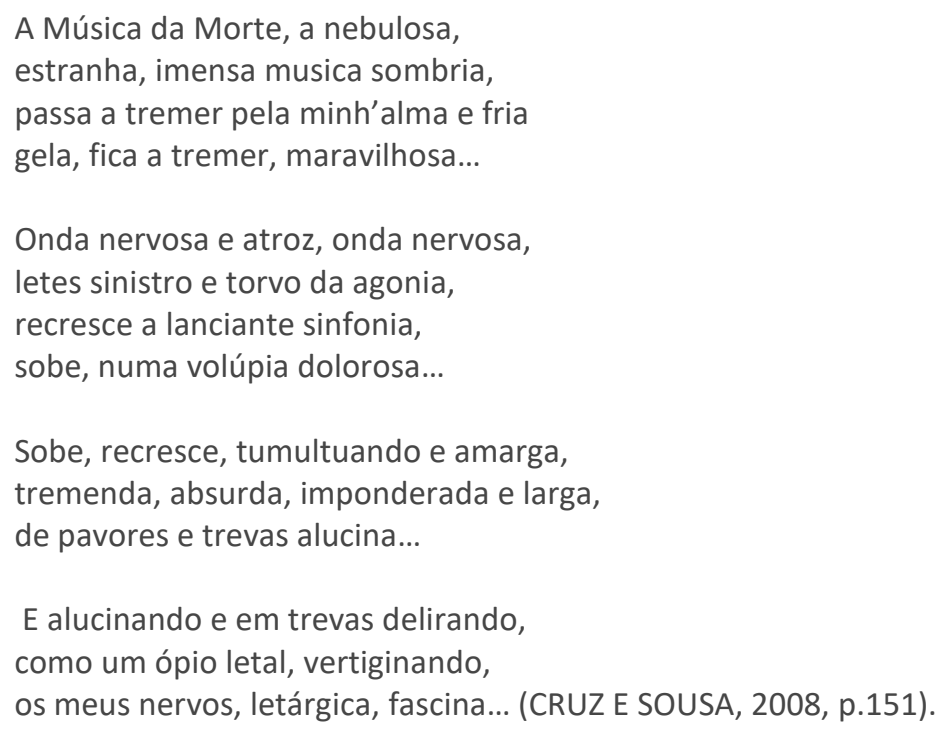

Nesse poema o eu lírico sente o rondar da morte sob sua vida, no entanto o que deveria causar espanto acaba fascinando o eu lírico. A música penetra cada vez mais no eu lírico e ele a sente adentrar a cada som em seus recônditos. Ele sabe que a música o está a embalar para a morte, mesmo assim deixa se encantar e penetrar em êxtase pelo sussurro da morte ao fim do poema. Há uma aceitabilidade da morte, pois ao mesmo tempo em que a música é sombria e dolorosa ela, também, fascina e é maravilhosa.

Sobre Cruz e Sousa, Afrânio Coutinho (1969) diz que foi provido de antenas sensibilíssimas para o incomensurável passado, cujas irradiações nele refletiam, muito embora, transcendental. A música das cores, das correspondências baudelairianas em estado latente, a música da palavra, - músicas complexas cheias de emotividade e imaginação, - comunicam-nos sua cosmovisão do Universo vivo. 
de importância total e igual, todos insubstituíveis. Porque surpreendera dois dos seus mais fieis amigos distraídos da leitura que o poeta, certa vez, fazia, - e apresentava, então, ao mundo "O Emparedado"! - Cruz e Sousa chorou... . . Suscetibilidade de quem sabia do preço único daquela hora, que nunca mais ocorreria. (COUTINHO, 1969, p.89).

Esta passagem em que Afrânio Coutinho se refere ao nosso poeta simbolista, considerando-o "uma voz nova na Poesia universal, expressão duma tragédia incomparável, vista, como deve ser, nos seus justos termos de essência." revela que Cruz e Sousa esteve sempre sob o espectro da morte como canta em sua "Música da morte".

\section{SINESTESIAS VISUAIS: AS CORES}

A sinestesia (do grego syn = junto, esthesia = sensação), figura de linguagem amplamente difundida na estética simbolista, é um recurso estilístico que se baseia na relação entre planos sensoriais, ou seja, a relação entre os diferentes sentidos humanos como, o olfato, a visão, o paladar, o tato e audição. Partimos do conhecimento da Teoria das Correspondências, ao que se convencionou chamar as correlações sensoriais que o poeta Charles Baudelaire faz em seu soneto "Correspondências". O eu lírico do poema defende a existência de uma relação entre os domínios sensoriais. Os sentidos humanos, portanto, possuem correlações misteriosas e estas conexões estão presentes na natureza das coisas.

Antonio Candido (1996, p.24) no livro O estudo analítico do poema refletindo sobre a expressividade dos sons diz que a sinestesia é a forma mais complexa de correspondência entre som - ou palavra, acrescentemos - e um sentido necessário ou simultaneidade de sensações. Portanto, a presença da sinestesia é evidente se num verso ou poema temos o uso de fonemas que remetem a um som e este se relacione com outro(s) sentido(s) ou, por outro lado, temos uma palavra em que se atribui um sentido relacionado a um dos planos sensoriais humanos a ela em consonância com outra a que se atribui outro plano sensorial.

Que tu não possas, Sentimento ardente,

Viver, vibrar nos brilhos do ar fremente,

Por entre as chamas, os clarões supernos.

Ó Sons intraduzíveis, Formas, Cores!...

Ah! que eu não possa eternizar as dores

Nos bronzes e nos mármores eternos!(CRUZ E SOUSA, 2008, p.102).

Percebemos nos versos acima retirados do poema "Tortura eterna" a interação do eu lírico, sons e cores revelam que a expressividade da sinestesia traduz a cosmovisão do eu lírico de maneira mais ampla e fidedigna à sensibilidade, pois a poesia simbolista, por se tratar em primazia de uma exteriorização dos sentimentos, da emotividade, emprega a sinestesia como figura de linguagem com maior capacidade expressiva para tal intuito, dada a trabalhar com os planos sensoriais humanos.

Cruz e Sousa seguiu à risca os preceitos da estética simbolista e das 
de subjetividade e expressividade, mas é sobretudo pelo uso das sinestesias que Cruz e Sousa realiza uma laboriosa e inovadora obra nas letras brasileiras, por ter conseguido imprimir na poesia nacional as inovações e perspectivas dos poetas franceses que demarcaram a existência da poesia pré e pós simbolista.

O poeta catarinense além do tão conhecido trabalho com os sons, pelo uso de aliterações e assonâncias, que trouxeram grande musicalidade a sua poesia, ele eternizou os sons dos violões chorosos de sua tão amada Nossa Senhora do Desterro em seu mais famoso poema "Violões que choram...", também se faz notar o seu trabalho no tocante às sinestesias visuais nas quais deixou impressos todo um espectro coral extremamente significativo em suas poesias, pois estas cores contribuem para o entendimento das mesmas.

\subsection{AS CORES}

As sinestesias visuais contêm as cores que corroboram para a composição imagística da poesia de Cruz e Sousa, por isso se constitui como um conhecimento importante para desvelar os segredos de sua poética. A luz influi na percepção das cores, dos objetos e do mundo, e é ela a grande responsável pela transitoriedade das cores nos poemas.

A cor é uma onda luminosa, um raio de luz branca que atravessa nossos olhos. É ainda uma produção de nosso cérebro, uma sensação visual, como se nós estivéssemos assistindo a uma gama de cores que se apresentasse aos nossos olhos, a todo instante, esculpida na natureza à nossa frente. (FARINA, PEREZ E BASTOS, 2006, p. 1).

Chevalier e Geehrbrant (1982) dizem em relação ao simbolismo das cores que sua primeira característica é a universalidade, que se expressa em todos os recônditos do ser e do conhecimento. Embora as cores sejam universais a todas as culturas e povos, o significado pontual de cada uma das cores varia de cultura para cultura, mas as cores permanecem, sobretudo como fundamentos do pensamento simbólico.

Por perceber, conforme já exposto, a enorme variedade de cores na poética cruzsouseana, é que incluímos em nosso estudo o levantamento das cores que estão presentes em seus poemas. Passamos a explicar como foi o percurso e o que foi considerado nesta etapa da pesquisa. Em princípio, foram considerados os adjetivos e os próprios vocábulos; alguns substantivos foram incluídos, desde que, estivessem em consonância com o encaminhamento semâtico do poema. Em relação ao branco, a luz não foi considerada enquanto cor, pois ela acaba revelando outras cores, já a treva, esconde as cores existentes no mundo, impedindo que nossa visão as percebam. Em relação à luz, ela pode ser de outras cores, como amarela, azul ou vermelha, já a treva necessariamente se liga ao preto. Quando se trata do azul, foram considerados apenas os adjetivos que remetem explicitamente a essa cor, embora haja a recorrência de vacábulos como céu, celeste, sidério, sideral que fortaleceram a percepção da cor azul relacionada ao livro Últimos sonetos.

Por causa da relatividade das cores, a pesquisa teve um percurso labiríntico, pois as cores ao mesmo tempo que especificam e particularizam os objetos, por 
vezes, os tornam misteriosos ou camuflados. No levantamento, muitas vezes, numa primeira leitura, identificamos uma cor, numa segunda leitura, mais atenta, percebemos que se tratava de outra cor, especialmente quando se relacionava à cor cinza, que pode ser entendida como uma cor de transição.

No levantamento, numa primeira análise, a cor cinza foi considerada branca, dado ser uma cor transitória entre as cores preta e branca, o cinza sempre vai oscilar entre uma das duas cores, ora se aproximando mais do preto, como nos termos obscuro, sombrio, etc; ora do branco, como os termos brumas, neblinas etc. Tais especificidades, muitas vezes, confundem o leitor da poesia cruzesouseana. Devido à flexibilidade que o significado das cores assume nos poemas permitem, por vezes, até incorporarem uma outra cor, porque um vocábulo que remete à determinada cor, pode se revelar, pelo encaminhamento semântico do poema, em outra cor.

Os três livros de Cruz e Sousa demonstram uma progressão trágica. Em Broquéis encontramos os temas mais alegres e coloridos de sua poesia, embora já prenunciem um quê trágico, que culmina em Faróis. Em contrapartida ao livro anterior, em Últimos sonetos o eu lírico reconcilia-se com sua tragédia, transcendentalizando-a nos recônditos do céu, do espaço.

\subsubsection{Broquéis: o livro branco}

Gráfico 1 - Cores em Broquéis

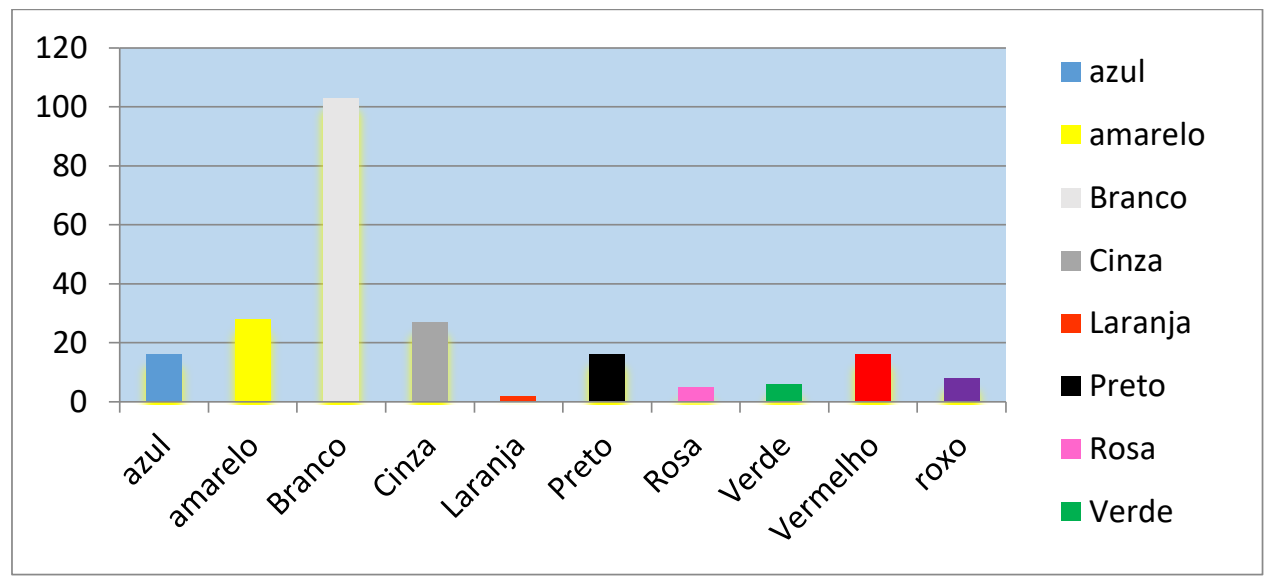

Fonte: Autoria própria (2017).

Este gráfico apresenta as cores encontradas nos poemas do livro Broquéis. Percebemos que há predominância para as cores branca, amarela, cinza, preta, vermelha e azul, sendo a primeira a mais utilizada (103 vezes). As demais, ficam distribuídas de forma mais proporcional, o que contribui para certo colorido ao livro. Outro detalhe que notamos é que, depois do cinza, as cores primárias (azul, vermelho e amarelo) ocupam papel de destaque no livro, seguida da cor preta. Nesta obra, a temática recorrente é envolta pela questão do amor carnal. Portanto, a cor branca reitera o tema que geralmente está associado ora à espiritualidade, ora à sensualidade.

Abaixo temos o poema Braços do livro Broquéis, nele há recorrência da cor branca. O poema trata da sensualidade, tema que é reiterado em Broquéis. 
brumais brancuras, fúlgidas brancuras, alvuras castas, virginais alvuras,

latescências das raras latescências.

As fascinantes, mórbidas dormências

dos teus abraços de letais flexuras, produzem sensações de agres torturas, dos desejos as mornas florescências.

Braços nervosos, tentadoras serpes que prendem, tetanizam como os herpes, dos delírios na trêmula coorte ...

Pompa de carnes tépidas e flóreas, braços de estranhas correções marmóreas abertos para o Amor e para a Morte! (CRUZ E SOUSA, 2008, p.54).

Percebemos a sensualidade na descrição dos braços da amada, notamos certo masoquismo sensual, pois ao mesmo tempo em que os braços são descritos idealmente na primeira estrofe, dado se referir a eles, além do branco, termos como virginais, castos e raros, por outro lado eles são nervosos. Na segunda estrofe, os braços são descritos como mórbidos e letais. Na terceira estrofe, ele reitera que os braços são nervosos. Além de todos esses termos que corroboram para uma descrição antitética destes "Braços", pois ora são usados adjetivos que os cultuam ora são usados adjetivos que os tornam agressivos, temos como que uma atração pelo sofrimento, pois o desejo é descrito de modo a infringir dor, pois ele considera o abraço de tais braços como "agres torturas" isso seria o início dos desejos. Na terceira estrofe, os braços assumem nuanças de tentadoras serpentes "que prendem, tetanizam como os herpes". Embora tais braços sejam capazes de causar todos esses males, o eu lírico como que enfeitiçado não consegue fugir dos seus afagos, e nos últimos versos, toda essa dor/prazer culminará no amor ou na morte.

A cor branca aqui se liga à beleza e à castidade, características prezadas no ser amado, embora toda essa simbologia se contraponha ao erotismo masoquista presente no poema. Sobre tal cor, Chevalier e Gheerbrant (1981, p.143) reiteram que "É a cor da pureza, que não é originariamente uma cor positiva, a manifestar que alguma coisa acaba de ser assumida; mas sim uma cor neutra, passiva, mostrando apenas que nada foi realizado ainda." Daí ser usada apenas na primeira estrofe quando se descreve os braços e à medida que vai descrevendo as intenções sensuais do eu lírico a cor branca não aparece mais. Destarte é interessante notar o contraponto do significado simbólico da cor e do braço, pois Pseo $^{1}$ (Apud CHEVALIER E GHEERBRANT, 1982, p.140) a respeito dos "Braços" diz que "As espáduas, os braços e as mãos, segundo Dionísio o Areopagita, representam o poder de fazer, de agir e operar", contribuindo para a compreensão dos significados opostos, pois enquanto o branco pode denotar algo por se fazer, os braços são facilmente relacionados às ações. 


\subsubsection{Faróis: o livro cinza}

Gráfico 2 - Cores em Faróis

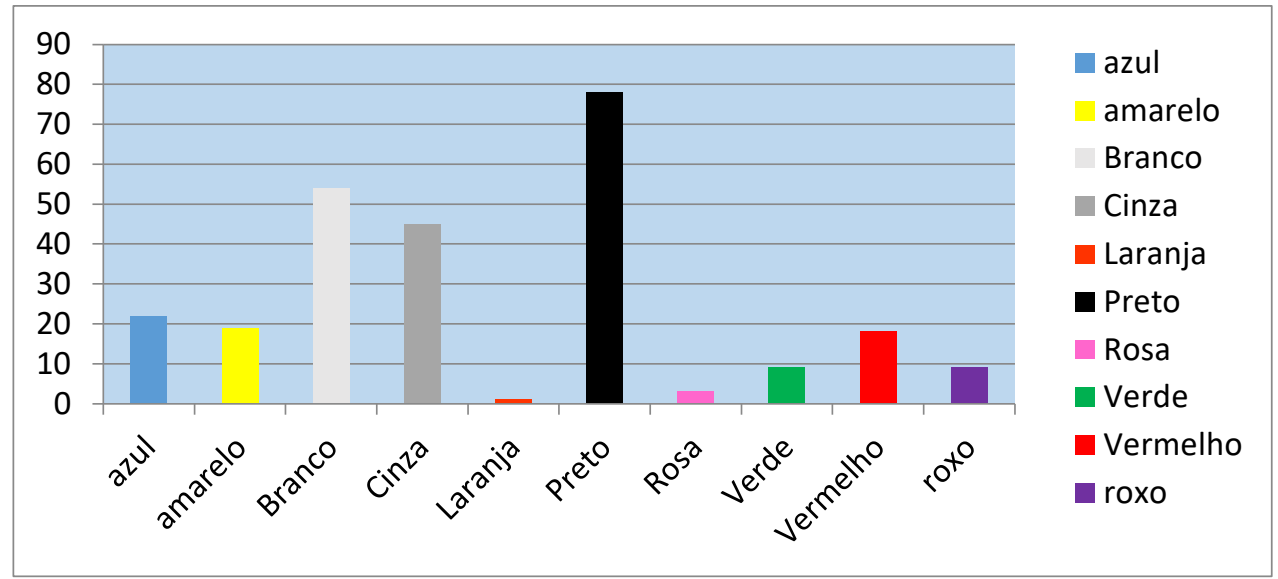

Fonte: Autoria própria (2017).

Este gráfico refere-se aos poemas do livro Faróis no qual, além do preto, que ganha em recorrência, algumas cores, que apareciam em Broquéis, recorrem em maior número de vezes como o cinza, azul, vermelho, roxo e verde. Muito embora fiquem atenuadas pelo uso demasiado das cores preta e branca. Podemos ver que a cor preta é preponderante, seguida de forma gradativamente decrescente pelas cores branca, cinza, azul, vermelha, amarela e roxa, esta última uma cor secundária originada da mistura entre as cores primárias azul e vermelha. Outras cores secundárias também são utilizadas (o verde e o laranja), mas em menor recorrência. Este levantamento permite-nos dizer que o contraste entre as cores preta e branca revela um tom acinzentado, que se configura como a grande cor deste livro. É interessante observar esta nuance porque uma cor depende também das relações que estabelece com as outras cores na expressão sígnica.

Em relação à cor cinza, Chevalier e Gheerbrant (1982) dizem que é composta em partes iguais de preto e branco, designando, na simbologia cristã, a ressurreição dos mortos. É a cor da cinza e da bruma. Os hebreus se cobriam de cinza para exprimir uma dor intensa. Para nós a cor cinza é uma cor de luto aliviado. O acinzentamento dos objetos quando descritos dão a impressão de tristeza, de melancolia, de enfado. Daí no poema "Violões que choram..." onde o eu lírico se reporta com um tom saudosista a sua cidade natal temos a descrição dos violões como sendo nevoentos.

Outro poema que podemos ver o acinzentamento das coisas e objetos é em "Ébrios e cegos", poema em que a cor é preponderante e, de certa forma, reitera o que dizem Chevalier e Gheerbrant:

Quanto aos sonhos que aparecem numa espécie de névoa acinzentada, situam-se nas camadas recuadas do Inconsciente, que precisam ser elucidadas e clarificadas pela tomada de consciência. Donde a expressão francesa se griser para "estar um tanto embriagado", i.e., no estado de obscurecimento da meiaconsciência. (CHEVALIER e GHEERBRANT, 1982, p. 248). 
O poema em questão dialoga bastante com as palavras finais do que Chevalier e Gheerbrant dizem tratar-se de um estado de obscurecimento da meia-consciência, pois no poema há a todo momento a cor cinza obscurecendo o ambiente, a cena como podemos ver nos seguintes trechos do poema:

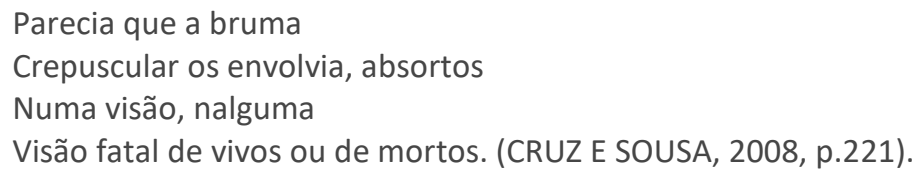

O eu lírico começa por descrever o ambiente dizendo se tratar de um fim de tarde sombrio, o céu estava nevoento e densamente chovia, tudo isso contribui para uma aura cinzenta que vamos percebendo ao longo do poema. Logo depois de descrever o ambiente e o clima, o eu lírico nos leva a acompanhar "Dous secretos mendigos", a expressão utilizada por Chevalier e Gheerbrant (1982, p.248) se griser se aplica ao andar dos dois mendigos como podemos ver nas seguintes estrofes:

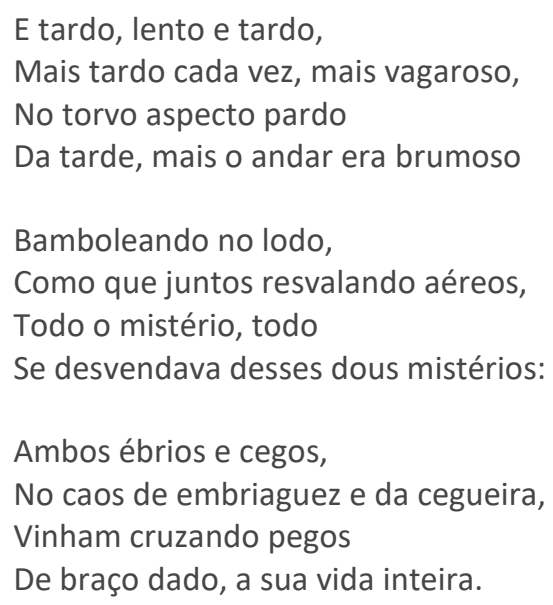

Ninguém diria, entanto,

O sentimento trágico, tremendo,

A convulsão de pranto

Que aquelas almas iam turvescendo. (CRUZ E SOUSA, 2008, p. 222).

O poema continua descrevendo o andar dos "dous secretos mendigos", até que nas últimas estrofes toda essa tristeza, todo esse acinzentamento culminará na treva:

Tão grande, tanta treva,

Tão terrível, tão trágica, tão triste,

Os sentidos subleva,

Cava outro horror, fora do horror que existe.

Pois do sinistro sonho

Da embriaguez e da cegueira enorme,

Erguia-se, medonho, 
Percebemos ao final do poema que a jornada tanto do ébrio quanto do cego terá fim no soerguimento do "fantasma desconforme" sobre suas vidas, que se trata do final a que toda vida humana está acometida, que é a chegada da morte. Ambos "Ébrios e Cegos" representam a jornada dos dois perfis humanos, pois todos nós estamos acometidos ou à embriaguez de nossos sonhos e desejos ou à cegueira da conformidade, normalidade, aceitação do destino. A caminhada cambaleante, embriagada, mostra os altos e baixos de nossas vidas, os obstáculos que todos enfrentamos, a caminhada que o poema descreve dos dois mendigos é a busca pela perpetuidade da vida "De almas que apostam duelar com a morte!", para o eu lírico a vida é um sinistro sonho ao qual a morte põe fim.

\subsection{3 Últimos sonetos: o livro azul}

Gráfico 1 - Cores em últimos sonetos

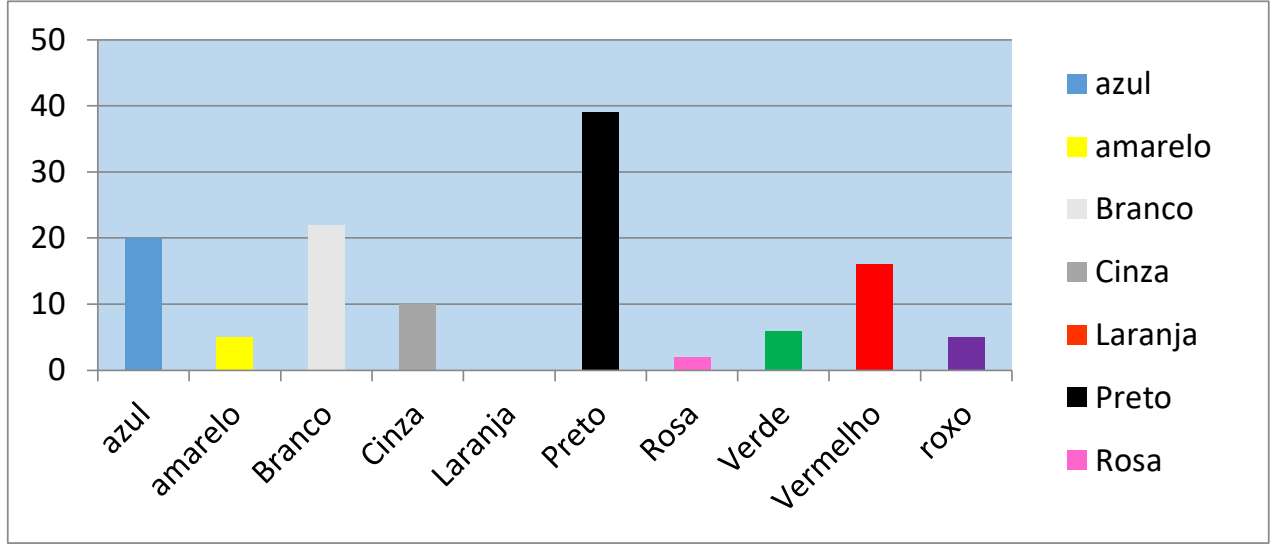

Fonte: Autoria própria (2017).

Neste livro, o preto continua sendo a cor predominante, muito embora o azul se revele de grande importância expressiva. A grande temática deste livro é a reconciliação com o sofrimento, portanto o azul vem auxiliar a manutenção temática do livro, pois esta cor está muito ligada à ideia de redenção, do céu cristão, conforme a ideologia religiosa cristã. O substantivo céu é corrente no livro, reforçando a ideia da cor azul. Assim, esta cor acaba sendo a mais importante deste livro devido à recorrência e à expressividade semântica que assume.

O azul que é tido como a cor mais profunda das cores: é uma cor fria, onde os nossos olhos descansam e são transportados a outros espaços, segundo Chevalier e Gheerbrant (1982), no livro Dicionário dos símbolos o azul é a mais imaterial das cores: a natureza o apresenta geralmente feito apenas de transparência, o azul é mais pura e fria das cores, à exceção do branco neutro. Assim, o conjunto de suas aplicações simbólicas depende dessas qualidades fundamentais. Chevalier e Gheerbrant dizem ainda:

Aplicada a um objeto, a cor azul suaviza as formas, abrindo-as e desfazendo-as. Uma superfície repassada de azul já não é mais uma superfície, um muro azul deixa de ser um muro. Os movimentos e os sons, assim como as formas, desaparecem no azul, afogam-se nele e somem, como um pássaro no céu. Imaterial em si mesmo, o azul desmaterializa tudo aquilo que dele se impregna. É caminho do 
infinito, onde o real se transforma em imaginário. (CHEVALIER E

GHEERBRANT, 1982, p.107).

Abaixo temos o poema "Sentimento esquisito", do livro Últimos sonetos, nele também encontramos recorrência da cor azul. O poema trata da reconciliação com a dor, da transcendência aos céus, temática preponderante neste livro.

Ó céu estéril dos desesperados,

Forma impassível de cristal sidéreo,

Dos cemitérios velho cemitério

Onde dormem os astros delicados.

Pátria d'estrelas dos abandonados,

Casulo azul do anseio vago, aéreo,

Formidável muralha de mistério

Que deixa os corações desconsolados.

Céu imóvel milênios e milênios,

Tu que iluminas a visão dos Gênios

E ergues das almas o sagrado acorde.

Céu estéril, absurdo, céu imoto,

Faz dormir no teu seio o Sonho ignoto,

Esta serpente que alucina e morde... (CRUZ E SOUSA, 2008, 307).

O poema começa com o vocativo "Ó céu" o que faz que identifiquemos um estabelecimento de uma comunicação entre o eu lírico e o "céu", os adjetivos usados para caracterizar o céu são estéril, impassível, azul, imóvel, absurdo e imoto, o adjetivo mais importante associado ao céu é o 'azul', confirmando o que dizem Chevalier e Geerhbrant em relação a esta cor:

Domínio, ou antes, clima da irrealidade - ou da super-realidade imóvel, o azul resolve em si mesmo as contradições, as alternâncias - tal como as do dia e da noite - que dão ritmo a vida humana. Impávido, indiferente, não estando em nenhum outro lugar a não ser em si mesmo, o azul não é deste mundo, sugere uma ideia de eternidade tranquila e altaneira, que é sobre-humana - ou inumana. (CHEVALIER E GHEERBRANT, 1982, p.107).

Percebemos um pedido, ou uma oração aos céus, que é o "Casulo azul do anseio vago, aéreo,/Formidável muralha de mistério" para que guarde os seus sonhos, que na terra fora ignorado. $\mathrm{O}$ eu lírico como que está a admirar o céu, e quer elevar os seus sonhos terrenos que aqui na terra não seriam possíveis de serem realizados para a permanência, eternidade do céu, o "Sonho branco" que outrora lhe lacerou o peito, pois é "serpente que alucina e morde...". O sonho, temática tão presente nos três livros de Cruz e Sousa, sempre fora a causa das frustrações do eu lírico, dado não ser realizado, desde Broquéis anunciava a fatalidade e insucessos de seus sonhos, como vemos nos últimos versos de "Sonho branco".

No poema, "Sentimento esquisito" o desejo do eu lírico volta-se para a possibilidade de transcendentalizar-se do sofrimento, a busca pelo sonho transcendente é uma possibilidade de realizar o que não consegue em vida, o 
que justifica a busca pela outra dimensão mais próxima dos elementos céus, cosmos e esferas que facilmente podem ser relacionadas ao que é azul.

\section{CONSIDERAÇÕES FINAIS}

Estes levantamentos estatísticos permitiram observar que as cores possuem uma relação semântico-temática com cada livro, ou seja, em Broquéis livro em que a grande temática fica a cargo do mundo espiritual e carnal, a cor predominante é branca, reforçando que esta cor, utilizada em demasia, contribui para os valores expressos e em consonância com a estética simbolista, de nada contribuindo para as suposições de um complexo de cor por parte do poeta.

Já em Faróis, o tema recorrente está relacionado à dor existencial. Aqui, a cor predominante é a preta, combinando perfeitamente para exprimir uma dor tão grande que parece ter na morte a solução para todos os problemas da existência. A dor chega a ser personificada, por exemplo, no poema "Meu filho", dele são os versos: "Mas, ah! eu vejo bem, sinistra, sobre o trono,/ A Dor, a eterna Dor, agitando o seu cetro!" (CRUZ E SOUSA, 2008, p. 176). Embora o preto seja a cor que aparece o maior número de vezes, o branco vem logo em seguida, ocupando papel de destaque. Com a mistura dessas duas cores, obtém-se a cor cinza, presente no livro todo em graduações que sugerem assim um enegrecimento, apagamento, embaçamento obscurecendo a vida e aniquilando o homem em sua própria dor.

Em Últimos sonetos, percebemos uma reconciliação com a dor presente no livro anterior e o céu antes acinzentado, mostra-se aqui desanuviado e límpido. 0 azul revela uma tranquilidade, contribuindo para o sentido da redenção da dor que outrora lacerava o peito do eu lírico. Esta cor é extremamente expressiva e contribui para reiterar a temática do livro. Podemos dizer se tratar da redenção, nestes termos, a cor se reveste de todo o misticismo cristão da recompensa e do paraíso post mortem.

O trabalho em questão partindo do ensaio de Roger Bastide intitulado "Quatro estudos sobre Cruz e Sousa" no qual defende a tese da "nostalgia do branco", pois a presença da cor branca nos poemas dos livros Broquéis e Missal chamou, em especial, a atenção do sociólogo francês que chegou a fazer uma estatística das cores em tais livros, apesar de tal cor ser bastante empregada na estética simbolista. A sua tese acabou contribuindo e perpetuando a ideia do "negro de alma branca" que fez com que o poeta brasileiro carregasse a imagem/estigma de poeta da cor branca nas letras brasileira o que gerou uma desconfortante situação haja vista a pertença étnica do poeta e seu importante papel na literatura brasileira, sendo um dos poucos escritores negros e de inconfundível ascendência africana a ocupar esse papel.

Contrariando a tese de Bastide que chegou a insinuar que Cruz e Sousa tivesse incorporado os padrões de escritas franceses e aderido ao Simbolismo porque queria "ocultar as suas origens, de subir racialmente, de passar, ao menos em espírito, a linha de cor" (BASTIDE, 1973, p. 159) vimos que as cores tem papel fundamental na poesia do poeta e que apresentam todo um espectro coral na lírica nacional e não se reduz a cor branca. A análise dos três livros de poemas nos permitiu ampliar o estudo de Bastide e verificar a recorrência de outras cores, embora foquemos nossas análises apenas na cor que prepondera em cada 
livro esse estudo abre perspectivas para outras análises que considerem as demais cores nas construções semântico-temáticas dos livros.

\title{
Cruz e Sousa's Colorful Liryc
}

\begin{abstract}
The present paper focus on study Cruz e Sousa's work, poet of singularity in Brazilian liryc. He was, undoubtly, fundamental to modern liryc of Brazil, because innovated his creative process, still tied in Parnassians models, to poetry, sheepish yet, of more free structure, abused in sensorial suggestions, mostly through visual synesthesias that confer enlarged meanings to his texts. Such characteristics, makes his production arrived to us like a color spectrum that make us have a cosmovision of his existential condition. The main object of this work is the preponderant colors in each book and its relation with the semanticthematic construction of analysed books. In this study, the analysis will be supported in notions of colors semantics of Chevalier e Gheerbrant. We also highlight the importance of Bastide studies, Coutinho and Moisés among others in our theoretical and analytical reasoning.
\end{abstract}

KEYWORDS: Cruz e Sousa. Visual synesthesias. Colors. 


\section{NOTAS}

${ }^{1}$ No livro O dicionário dos símbolos Chevalier e Gheerbrant (1981) citam Dionísio - Areopagita, conhecido também como Pseudo-Dionísio, no livro os autores usam o nome PSEO para se referir ao autor de um conjunto de texto intitulado Corpus Areopagiticum que influenciou substancialmente a mística crista durante a idade média no ocidente.

\section{REFERÊNCIAS}

BASTIDE, Roger. Estudo Afro-Brasileiros. São Paulo: Perspectiva S.A., 1973.

BAUDELAIRE, Charles. As flores do mal. São Paulo: Editora Matin Claret, 2011.

CANDIDO, Antonio. O estudo analítico do poema. São Paulo: Humanitas Publicações/FFLCH/USP, 1996.

CHEVALIER, Jean; GHEERBRANT, Alain. Dicionário de símbolos: Mitos, sonhos, costumes, gestos, formas, figuras, cores, números. 2. ed. Rio de Janeiro: José Olympio, 1982.

COSTA, Ana Lucia Faria. Simbolismo e Impressionismo: um apelo aos sentidos. № 6 - Revista MELP, USP, São Paulo, Faculdade de Educação, nov. de 2011.

COUTINHO, Afrânio. A literatura no Brasil vol. IV: Simbolismo - impressionismo transição. 2. ed. Rio de Janeiro: Editora Sul Americana S. A, 1969.

CRUZ E SOUSA, João da. Cruz e Sousa simbolista; Broquéis; Faróis; Últimos sonetos. Organização e estudo por Lauro Junkes. - Jaraguá do Sul: Avenida, 2008.

FALEIROS, Álvaro. Verso e reverso: alguma presença francesa na poesia brasileira. Itinerários, Araraquara, n. 31, p.175-186, jul./dez. 2010.

FARINA, Modesto; PEREZ, Clotilde, BASTOS, Dorinho. Psicodinâmica das cores em comunicão. 5. ed. ver. E ampl. São Paulo: Edgard Blucher, 2006.

MOISÉS, Massaud. História da literatura brasileira: Simbolismo. São Paulo: Cultrix, 1984. 
Recebido: 10 set. 2016

Aprovado: 06 ago. 2017

DOI: $10.3895 /$ rl.v19n25.4620

Como citar: BARROS, Adailton Almeida. A lírica colorida de Cruz e Souza. R. Letras, Curitiba, v. 19, n. 25, p. 70-86, jan./jun. 2017. Disponível em: <https://periodicos.utfpr.edu.br/rl>. Acesso em: XXX.

Direito autoral: Este artigo está licenciado sob os termos da Licença Creative Commons-Atribuição 4.0 Internacional.

(c) (1) 